\title{
Folklore Local Wisdom Values of Rembang Society
}

\section{Mohammad Kanzunnudin', Fathur Rokhman², Suminto A. Sayuti ${ }^{3}$, Hari Bakti Mardikantoro ${ }^{4}$}

\author{
${ }^{1}$ Universitas Muria Kudus, Indonesia \\ ${ }^{2,4}$ Graduate School, Universitas Negeri Semarang, Indonesia \\ ${ }^{3}$ Universitas Negeri Yogyakarta, Indonesia \\ Corresponding email: mohammadkanzunnudin@yahoo.com
}

\begin{abstract}
This study aimed to dig out the folklore local wisdom values of Rembang Society through folklore i.e. Pantangan Menanam Kedelai, Talas, dan Ketan Hitam, Putri Cempa, and Asal-usul Desa Pamotan. There were local wisdom in these folktale like a leadership, devotion, tradition, culture, and social values. A qualitative descriptive and ethnography method were used in this study. The data were collected via literature review, observation, deep interview, recording, writing, and shooting. The data also well-collected realistically and critically. This study deal the folktale had the local wisdom values i.e. 1) leadership, devotion, tradition, culture, and social. However, the devotion and social values were dominant in this story.
\end{abstract}

Keywords: Local Wisdom Values, Folklore, Rembang Society.

\section{Introduction}

Rembang Regency (hereinafter referred to as Rembang) is the East Coast of East Central Java which is located at the easternmost tip of Central Java Province, Indonesia. Rembang, as a regency city, administrative area is divided into 14 districts, and has 287 villages.

Rembang as a coastal area (coast) based on Javanese cultural point of view is a community area that is in a small tradition. Kartodirdjo (1986: 409-410) states that Javanese culture has two subcultures, namely large traditions and small traditions. Great traditions are found in palaces and towns, around the city of Solo and Yogykarta. As for small traditions living outside or away from the palace. According to Thohir (2006: 45) the small tradition in culture has many folklore that grow and develop in the middle of life.

Based on the cultural context, the researchers are very interested to do research folklore in Rembang. In this study, the researcher limits to researching only three very famous folklore for Rembang people, namely the story "Pantangan Planting Soybean, Talas, and Ketan Hitam", "Putri Cempa", and "Origin of Pamotan Village". The research focuses on the value of local wisdom contained in the three stories.

\section{Methods}

This research applies qualitative approach with ethnography method. Moleong (2001: 3$6)$, qualitative research as a research procedure that produces descriptive data in the form of written or oral words of people and observed behavior. The data collected in the form of words, images, and not the numbers; while the research report contains data citations to illustrate the presentation of reports. The data may be from interviews, field notes, photographs, videotapes, personal documents, notes or memos, and other official documents (see Satori and Aan Komariah, 2014: 28, Miles and A. Michael Huberman, 2007 : 15; and Rohidi, 2001).

The ethnographic method focuses on understanding the system of cultural meanings (Spradley, 2007: 10; and Rokhman, 2005: 1920). The ethnography is implemented, namely realist ethnography and critical ethics. Creswell (2015: ix) describes the realist ethnography that puts the researcher as an objective observer, recording facts with impartiality. The critical ethnography puts researchers to be critical. Implementation of both types of ethnography is known by the term holistic ethnography, ie ethnography which in its analysis utilizes emic data (views of participants) and ethical data (researcher's view).

\section{Result \& Discussion}

Experts have offered insights into folklore (Hutomo 1991: 1; Sudjiman 1984: 16; Rampan 2014: 1-2; Endraswara 2009: 28; Brunvand 1978: 23; Harvilahti 2003: 200; Sims and Martine Stephens 2005: 1; and 
Kanzunnudin, Fathur Rokhman, Suminto A. Sayuti and Hari Bakti Mardikantoro 2017: 175-182), it can be concluded that folklore is part of collective culture inherited by the ancestors (ancestors) to future generations through oral and written culture down heredity that contains the values of life with various variations of form such as prose (tales, myths, legends), puzzles, tembang, folk poetry (pantun, gurindam, poetry), folk language (dialect), poetry, customs, , gestures for people's communication (kentongan, drum), traditional dress, folk music.

This definition shows that folklore consists of how many types. Danandjaya (1994: 21-22) and Cokrowinoto (1986: 505), divide into three major groups. First, oral folklore as a folklore whose form is purely oral. Such as (a) folklore (accent, nickname, traditional rank, and noble title); (b) traditional expressions, such as proverbs, proverbs and retributions; (c) traditional questions, such as puzzles; (d) people's poetry such as rhymes, gurindam, and poetry; (e) folk prose stories, such as myths, legends, and fairy tales; and (f) people's songs.

Secondly, the folklore is partly oral, ie the form is a mixture of oral and non-verbal elements. For example, people's trust consisting of oral statements coupled with gestures that are considered to have supernatural meanings, such as the sign of the Cross for Christians. Other forms such as folk games, folk theater, folk dance, customs, ceremonies, and folk festivals.

Thirdly, non verbal folklore is a folklore whose form is not verbal although the way of making it is taught orally. This group is divided into two subgroups, ie the material and the non material. Folklore forms that include classes of materials such as folklore architecture (original house form, rice barn form, and the like), people's handicrafts, clothing and adat body jewelry, food and beverages, and traditional medicines. As for non-material folklore such as gestures, gestures for popular communications (kentongan alarms in Java), and folk music. Regarding the types of folklore, then in this discussion that researched oral folklore in the form of prose folklore, namely mite, legend, and fairy tales.

Sulaeman (1998: 19) reveals the value of something that human beings are concerned with as subject, concerning everything good or bad as abstractions, views, or intentions of experiences with strict behavior selection. Similarly, Koentjaraningrat (1990: 190) understood that values are important, valuable, and important concepts that live in the minds of the people and serve as guidelines that give direction and orientation to the life of the people concerned (see Ihsan 2010: 235-236; and Kosasih 2015).

Based on the opinions of experts it can be concluded that value is something or concept of high value and very important that is believed or believed, respected, and made the basis in acting individually or a group of a society. The concept becomes a benchmark or a good-bad, beautiful-bad, right-wrong, unjustbased norm in a cultural context. Therefore, values are binding to a person or group of people of a society in thinking, speaking, and acting.

Sudikan (2013: 42) states that wisdom is the attitude, view, and ability of a community in managing its spiritual and physical environment, which gives the community its endurance and power to grow within the area where it is located. The values of local wisdom are contained in the local cultural treasures of tradition, the proverbs, and the motto of life. Meanwhile, Sayuti (2013) states that the values of local wisdom are a set of local cultural values and roots such as traditions, community experiences, and local knowledge that are a core part of culture (Sayuti, 2008: 28).

Based on the expert's opinion, it can be concluded that local wisdom is thought, attitude, view, belief (ideology), ability which is the result of collective thinking of a society whose positive values (noble values) have been tested by the passage of time, traditions, norms, ethics, and values that are believed and actualized in behavior by the community of their owners.

\section{Story Value Prohibition Planting Soybean, Taro, and Black Stick}

The value of local wisdom contained in the story of "The Prohibition of Soybean, Talas, and Ketan Hitam" includes values (1) devotion, (2) tradition, (3) culture, and (4) social.

The value of devotion, expressed through the character $\mathrm{Ki}$ Ageng Asem Kethek who dedicate himself in a forest that is still empty uninhabited to become a village named village 
Bulu. A village inhabited by the descendants of Ki Ageng Asem Kethek and people who came from all directions and lived in the village of Bulu. It shows that Ki Ageng Asem Kethek's actions are not for himself but for the benefit of the general public. Ki Ageng Asem Kethek's action is the actualization of the value of dedication.

Traditional values, explained through messages instructed by Maling Kopo and Maling Kenthiri to the generations of $\mathrm{Ki}$ Ageng Asem Kethek who are not allowed to plant three types of plants, namely Soybean, Talas, and Ketan Hitam, so that the occupied territory there is no disturbance whatsoever. Amanah is implemented by $\mathrm{Ki}$ Ageng Asem Kethek. Even the tradition is still implemented by the descendants of Ki Ageng Asem Kethek. The value of culture, narrated through alms and selamatan conducted by the villagers Bulu. Residents of Bulu village every Friday Legi month of Suro as a sign of gratitude to God, and on the day of Rebo Pon people also do salvation and alms to commemorate the services of his ancestors in the cemetery $\mathrm{Ki}$ Ageng Asem Kethek. Social value, indicated by the social interaction among members living in the village of Bulu. Also the interaction and communication of Bulu villagers who do alms and salvation continuously every year as a manifestation of gratitude to God Almighty.

\section{The Value of Local Wisdom of Princess Putri Earthquake}

The story of "Putri Cempa" has the value of local wisdom of (1) devotion, (2) tradition, (3) culture, and (4) social. The value of devotion, expressed through the Princess Putri Cempa who volunteered himself devoted himself to the second husband, namely Arya Damar Regent of Palembang. Likewise, the Princess of Cempa who fully devoted himself as a disciple to Sunan Bonang who is very faithful to his life to learn the religion of Islam. With his totality of being a disciple and studying Islam, then after Princess Cempa died, finally gained recognition and respect for society by placing himself as a respected woman. This is proven Princess Cempa buried close to Pasujudan Sunan Bonang and always diziarahi by the pilgrims Pasujudan Sunan Bonang.

The value of tradition, explained in the form of a tradition of appreciating the souls of the dead, especially the spirits of those who are meritorious in spreading the values of good and religious. As the tradition of pilgrimage to people who have championed the values of society and religion, such as pilgrimage to Princess Earthquake. Princess Cempa as a disciple of Sunan Bonang who is very loyal as well as helping Sunan Bonang in disseminating Islamic values, his services are highly appreciated. Therefore, despite his death, his grave visited or visited by people from various regions.

The value of culture, expressed through events or pilgrimage activities conducted by people who make the pilgrimage. Activities or pilgrimage activities to the grave of Princess Cempa as well as to Pasujudan Sunan Bonang. Pilgrimage activity is a cultural activity that has been "mentradisi", which is a tradition for the community. It is a sign of love and respect of the community to Princess Cempa. Social value, shown through the movements and activities of the members (groups) who make a pilgrimage that directly affects the interaction and communication between members (groups) who make a pilgrimage or between groups that make pilgrimages with local communities (original) in the place of pilgrimage.

\section{The Value of Local Wisdom Story Origin Pamotan Village}

The story of "Origin of Pamotan Village" has the value of local wisdom that includes values (1) leadership, (2) the value of the ministry, and (3) social.

The value of leadership, shown through the character Ki Ageng Pamot who wise to the opinion of his daughter, Dewi Umbul Sari. When many of the nobles and the masters of different directions were about to apply and marry Dewi Umbul Sari; all decisions are submitted to Dewi Umbul Sari. Likewise, when Dewi Umbul Sari held a contest, Ki Ageng Pamot was neutral and did not affect her daughter's attitude. Ki Ageng Pamot gave his daughter's independence to make decisions so long as it did not harm her or anyone else. Likewise, as a family leader, he is responsible for the water shortages his family experiences when the dry season arrives; until finally he can handle it.

The value of devotion, expressed through the character of Ki Ageng Pamot who opened the forest to become a village called Pamotan. 
Ki Ageng Pamot devoted himself to doing something that the result is intended for the people or the community, which is to open the forest into a village and open up agricultural land that can be utilized by other people or society. Social value, explained through event contest held by Dewi Umbul Sari. The contest event generates reactions and communication among its various social layers and various corners of its origin. Event contest gave birth to aspects of religion because the purpose of the competition to create a source of water or springs is very useful for human life and agriculture.

Based on the third analysis of the prose story of the people of Rembang community, it shows the value of local wisdom in the form of values of leadership, dedication, tradition, social, and culture. The value of leadership which is one of the social aspects is revealed by the story in line with the results of research conducted by Janthaluck and Wilailak Qunjit (2012) and Neustadt (1986) that folklore has value related to social structure.

The value of devotion as one of the actual content of the Rembang people's folklore, in accordance with the opinion of Danandjaja (2008: 58) which reveals that folklore has a usefulness or function in collective or collective life. Danandjaja's statement implies that one of the functions in social life for someone when developing the value of dedication, that can be "service" for the community or others. A person who is willing to do good for the benefit of others or the general public.

The existence of traditional values as one of the values of local wisdom, stressed that the people of Rembang are very concerned with the embodiment of traditions that are directly related in daily life. This is in line with the results of Bosch's analysis (2009) that folklore is an appropriate means to inculcate traditional values for the story-telling community. The prose story of Rembang people also contains social values. This is in line with Orian's opinion and Jucan's fund (2013), that folklore can not be separated from sociological objects. Even Bronner (2012) insists that through folklore one can understand the oral and social societies.

Regarding the cultural values contained in the prose story of the people of Rembang, according to the empirical reality of research results Shaev and Elena Samoylova (2013), that folklore contains cultural phenomenon. Folklore reflects the cultural value of the owner. Therefore, folklore has a special cultural value in accordance with the context of its owner community.

\section{Conclusion}

Based on the analysis of the three folk prose stories titled "Pantangan planting Soybean, Talas, and Ketan Hitam"; "Putri Cempa", and "The Origin of Pamotan Village" show that the Rembang people's folklore has local wisdom values in general in terms of leadership, service, tradition, social, and culture values. Regarding the value of local dominant wisdom based on the analysis of the three stories of prose people of Rembang people, namely the value of dedication and social.

\section{References}

Bosch, Mineke. 2009. "Between Entertainment and Nationalist Politics: The Uses of Folklore in the Spectacle of the International Woman Suffrage Alliance" . Women's Studies International Forum 32 (2009) 2-4. journal homepage: www.elsevier.com/locate/wsif

Bronner, Simon J. 2012. "Practice Theory in Folklore and Folklife Studies". Folklore 123 (April 2012): 23-47. http://dx.doi.org/10.1080/0015587X201 2.642985 .

Brunvand, John Harold. 1978. The Study of American Folklore: An Introduction. New York: WW Norton \&Company Inc.

Cokrowinoto, Sardanto. 1986. "Manfaat Folklore bagi Pembangunan Masyarakat" dalam Soedarsono (Ed.) Kesenian, Bahasa dan Folklore Jawa. Yogyakarta: Proyek Penelitian dan Pengkajian Kebudayaan Nusantara (Javanologi) Direktorat Jenderal Kebudayaan Departemen Pendidikan dan Kebudayaan.

Creswell, John W. 2015. Qualitative Inquiry \& Research Design: Choosing Among Five Appoaches. Terjemahan Ahmad Lintang Lazuardi. Yogyakarta: Pustaka Pelajar. 
Danandjaja, James. 1994. Folklor Indonesia: Ilmu Gosip, Dongeng, dan lain-lain. Jakarta: Grafiti.

Danandaja, James. 2008. "Pendekatan Folklor dalam Penelitian Bahan-Bahan Tradisi Lisan" dalam Pudentia MPSS (Ed.) Metodologi Kajian Tradisi Lisan. Jakarta: Asosiasi Tradisi Lisan.

Endraswara, Suwardi. 2009. Metodologi Penelitian Folklor: Konsep, Teori, dan Aplikasi. Jakarta: Medpress.

Harvilahti, Lauri. 2003. "Folklore and Oral Tradition". Oral Tradition 18/2 (2003): 200-202. Helsinki: Finnish Literature Society.

Hutomo, Suripan Sadi. 1991. Mutiara Yang Terlupakan: Pengantar Studi Sastra Lisan. Surabaya: HISKI.

Ihsan, H.A. Fuad. 2010. Filsafat Ilmu. Jakarta: Rineka Cipta.

Janthaluck, Maneerat dan Wilailak Qunjit. 2012. "Folklore, Restoration of Social Capital and Community Culture". Procedia Social and Behavioral Sciences. 65. Hlm. 218-224.

Kanzunnudin, Mohammad, Fathur Rokhman, Sayuti A. Suminto, dan Hari Bhakti Mardikantoro. 2017. "Structure and Values of Story Pross of the People of Kudus Society". International Journal of Economic Research. Volume Volume 14. Number 12. Hlm. 175-182.

Kartodirdjo, A. Sartono. 1986. "Suatu Tinjauan Fenomenologi Folklor Jawa" dalam Soedarsono (Ed.). Kesenian, Bahasa dan Folklor Jawa. Yogyakarta: Departeen Pendidikan dan Kebudayaan.

Koentjaraningrat. 1990. Pengantar Ilmu Antropologi. Jakarta: Rineka Cipta.

Kosasih, H. Aceng. 2015. Konsep Pendidikan Nilai. File.upi.edu/direktori/FPIPS/MK-D-U/diunduh pada 10 april 2015

Miles, Matthew B. dan A. Michael Huberman. 2007. Analisis Data Kualitatif: Buku Sumber tentang Metode-metode Baru. Penerjemah Tjetjep Rohendi Rohidi. Jakarta: Universitas Indonesia.

Moleong, Lexy J. 2001. Metodologi Penelitian Kualitatif. Bandung: Remaja Rosdakarya.

Neustadt, Katherine D. 1986. " The Nature of Woman and the Development of
American Folklore". Woman's Studies In Forum. Vol. 9 No. 3 Hlm. 227-234.

Orian, Georgeta dan Dana Jucan. 2013. "Learning Situations within an Informal context: Case Study (Etnology and Folklore Course)". Procedia Social and Behavioral Sciences. 76. Hlm. 575-580.

Rampan, Korrie Layun. 2014. Teknik Menulis Cerita Rakyat. Bandung: Yrama Widya.

Rohidi, Tjetjep Rohendi. 2001. Metodologi Penelitian Seni. Semarang: Cipta Prima Nusantara.

Rokhman, Fathur. 2005. Pemilihan Bahasa Masyarakat Dwibahasa di Banyumas: Kajian Sosiolinguistik. Semarang: Rumah Indonesia.

Satori, Djam’an dan Aan Komariah. 2014. Metodologi Penelitian Kualitatif. Bandung: Alfabeta.

Sayuti, Suminto. 2008. "Bahasa, Identitas, dan Kearifan Lokal dalam Perspektif Pendidikan" dalam Mulyana (Ed.) Bahasa dan Sastra Daerah dalam Kerangka Budaya. Yogyakarta: Tiara Wacana.

Sayuti, Suminto A. 2013. Kearifan Lokal dan Kurikulum 2013: Perspektif Pembelajaran Sastra Indonesia. Makalah disajikan dalam Seminar Nasional Program Pascasarjana Unnes, Semarang, 22 Desember.

Shaev, Yury dan Elena Samoylova. 2013. "The Semiotic of Archetypes and Images in the Folklore of Andes Region". Procedia Social and Behavioral Sciences. 92. Hlm. 863-867.

Sims, Martha C. \& Martine Stephens. 2005. Living Folklore: An Introduction to the Study of People and Their Traditions. Logan Utah: Utah State University Press.

Spradley, James P. 2007. Metode Etnografi. Terjemahan Misbah Zulfa Elizabeth. Yogyakarta: Tiara Wacana.

Sudjiman, Panuti. 1984. Kamus Istilah Sastra. Jakarta: Gramedia.

Sudikan, Setyo Yuwana. 2013. Kearifan Budya Lokal. Sidoarjo: Damar Ilmu.

Sulaeman, M. Munandar. 1998. Ilmu Budaya Dasar: Suatu Pengantar. Jakarta: Refika Aditama.

Thohir, Mudjahirin. 2006. Orang-Orang Islam Pesisiran. Semarang: Fasindo Press. 